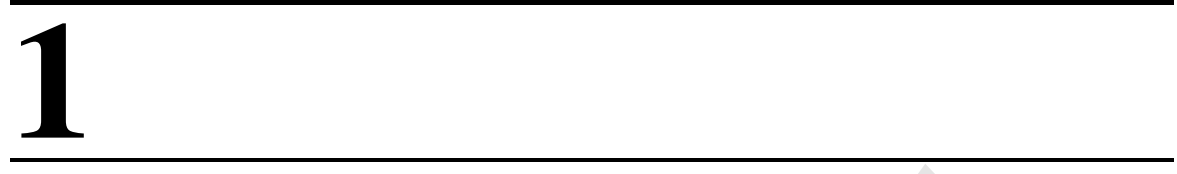

\title{
INTRODUCTION TO DRINKING WATER RISK ASSESSMENT
}

\author{
Robert A. Howd \\ California Environmental Protection Agency, Oakland, California
}

The need for a clean and safe drinking water supply for centers of population has been recognized for over 2000 years. The early Romans recognized that human activities and effluent were a major source of water pollution, and that providing water from relatively unpopulated areas was a solution to the problem. In 312 B.C. the Romans under Appius Claudius began development of an aqueduct system to deliver water taken from the Tiber River upstream of the city, thus improving the quality and quantity of their water supply (Okun, 2003). It has been said that the availability of a good water supply through their extensive aqueduct system enabled the rise of Rome as a center of civilization-and it has also been speculated that the use of lead for water pipes helped lead to its downfall, through slow poisoning of the population. This has been disputed, with evidence that terra-cotta was a preferred piping material, resulting in better-tasting drinking water. Thus, the maintenance of drinking water quality has been a major quest throughout the development of modern civilization.

However, it was not until the efforts of John Snow in 1854, analyzing a cholera epidemic in London, that specific diseases were shown to be associated with drinking waters that looked and tasted clean. For those who may not have heard the story, John Snow, a London doctor, noticed that many of the people who died of cholera in that summer's epidemic had a common factor; they all obtained their drinking water through the Broad Street well. He had the pump handle removed and the epidemic faded away. For this analysis and his subsequent publications,

Risk Assessment for Chemicals in Drinking Water, Edited by Robert A. Howd and Anna M. Fan Copyright (C) 2008 John Wiley \& Sons, Inc. 
John Snow is credited as being the father of epidemiology. An excellent summary of these events is available at the Web site of the University of California-Los Angeles, at http://www.ph.ucla.edu/epi/snow.html.

If the slow progress of development of safe drinking water supplies from early Roman times until the mid-nineteenth century seems strange to us today, we should recall that the "germ theory" of disease wasn't elucidated by Louis Pasteur until two decades later, in the late 1870s. Recognition that bacteria were major causes of diseases, that these bacteria could be distributed in drinking water, and that removing the bacteria would protect the population from important diseases such as cholera and typhoid eventually followed.

In the United States, water quality was at first maintained in exactly the same way as in ancient Rome, primarily by transporting clean water through pipes and canals from sparsely populated regions. The need and purpose were exactly the same: to protect the drinking water supply from sewage contamination. However, transporting water over large distances is expensive, and obtaining water from nearby rivers and streams was seen by many municipalities as a preferred option. Filtration through sand was instituted in the late nineteenth century to clarify the water and decrease the bacterial contamination. This step decreased the incidence of cholera, but it soon became obvious that this was not adequate. The incidence of waterborne illnesses such as cholera and typhoid was observed to correlate with the source of the drinking water supply in major American cities, even after filtration was instituted (Okun, 2003; Pontius, 2003). Removal of bacteria by chemical disinfection began to be evaluated.

Chlorination of drinking water for bacteriological control was begun in the United States in 1908 (in Boonton, New Jersey), although it had been studied extensively before that time in both Europe and the United States (Baker, 1948). The treatment was quickly demonstrated to make a tremendous difference in disease transmission. The discoveries leading to the technique are considered to be one of the greatest public health breakthroughs of all time, preventing millions of illnesses and deaths.

\section{DEVELOPMENT OF DRINKING WATER REGULATIONS}

The first regulations for drinking water purity were primarily for bacteriological control, beginning with the U.S. Public Health Standards of 1914. These first standards applied only to water used in interstate commerce. However, eventually all 50 states adopted comparable standards for their public water supply systems (U.S. EPA, 1999). Drinking water standards for chemicals were introduced in the U.S. Public Health Standards amendments in 1925, which included standards for lead, copper, and zinc. A few more metals were added in the amendments of 1942. By 1962, the 28 constituents or properties listed in Table 1 were regulated by the U.S. Public Health Service (U.S. DHEW, 1969).

Information on the potential health effects of contaminants in drinking water, particularly those derived from the developing chemical industries, accumulated 
TABLE 1. Contaminants Regulated Under the 1962 Public Health Service Standards

\begin{tabular}{ll}
\hline Alkyl benzene sulfonate & Lead \\
Arsenic & Manganese \\
Barium & Nitrate \\
Beta and photon emitters & Phenols \\
Cadmium & Radium-226 \\
Carbon chloroform extract & Selenium \\
Chloride & Silver \\
Chromium & Strontium-90 \\
Color & Sulfate \\
Copper & Threshold odor number \\
Cyanide & Total coliform \\
Fluoride & Total dissolved solids \\
Gross alpha emitters & Turbidity \\
Iron & Zinc \\
\hline
\end{tabular}

Source: Adapted from U.S. EPA (1999).

through the 1960s and early 1970s. Hueper (1960) reported that cities in Holland that obtained drinking water from rivers had higher cancer rates than did cities that used groundwater. Nobel laureate Joshua Lederberg pointed out in a Washington Post column that disinfection with chlorine was likely to form mutagenic compounds (Lederberg, 1969). A U.S. Environmental Protection Agency (EPA) study (U.S. EPA, 1972) identified 36 organic chemicals in finished drinking water from a New Orleans water treatment plant, accompanied by many more unidentified compounds. Page et al. $(1974,1976)$ then reported that cancer rates were higher in Louisiana cities that obtained their drinking water from the Mississippi River. These concerns led to passage of the federal Safe Drinking Water Act (SDWA) in 1974 "to assure that water supply systems serving the public met minimum national standards for protection of public health."

The SDWA authorized the EPA to set national health-based standards for drinking water to protect against both naturally occurring and human-made contaminants in drinking water (U.S. EPA, 1999, 2004). The SDWA, especially after further amendments in 1986 and 1996, requires many actions to protect drinking water and its sources (rivers, lakes, reservoirs, springs, and wells). The SDWA applies to every public water system in the United States, but does not regulate private wells that serve fewer than 25 people. The act sets up a system under which the EPA, states, and water systems work together to make sure that the standards are met.

Originally, the SDWA focused primarily on water treatment to ensure safe drinking water. The 1996 amendments expanded the law by recognizing source water protection, operator training, funding for water system improvements, and providing information to the public as important components of the drinking water delivery system. The National Primary Drinking Water Regulations implemented by the EPA under the SDWA provide for national science- and public 
health-based standards for drinking water, considering available technology and costs. The regulations set enforceable maximum contaminant levels (MCLs) for contaminants in drinking water or required ways to treat water to remove contaminants. In addition to setting the standards, the EPA provides detailed guidance and public information about drinking water issues, compiles drinking water data, and oversees state drinking water programs.

Drinking water supply systems are regulated directly by state drinking water programs. The states applied to the EPA for the authority to implement the SDWA within their jurisdictions (primacy), which required the adoption of standards at least as stringent as the EPA's, as well as a supporting inspection and regulatory system. All states and territories except Wyoming and the District of Columbia have received primacy. The responsible agency, called the primacy agent, makes sure that water systems test for contaminants, reviews plans for water system projects, conducts inspections and sanitary surveys, and provides training and technical assistance. The primacy agent is also responsible for taking action against water systems that are not meeting the standards.

To aid in the development of national standards for tap water, the EPA prioritizes contaminants for potential regulation based on risk and how often they occur in water supplies. The EPA conducts a risk assessment for each chemical and sets a maximum contaminant-level goal (MCLG) based on health risk (including risks to sensitive subpopulations, e.g., infants, children, pregnant women, the elderly, and the immunocompromized). The agency also performs a cost-benefit analysis for each standard and obtains input from interested parties to help develop feasible standards. The EPA sets the MCL for the contaminant in drinking water (or a required treatment technique) as close to the health goal as they judge to be feasible.

States then adopt the new standards and are given two or more years to bring their regulated water systems into compliance. The provision in the law that state standards may be more stringent if deemed appropriate is intended primarily to allow a higher purity standard if it is economically feasible in a given region. For example, the federal standard for arsenic in drinking water was set at $10 \mathrm{ppb}$ (a very high cancer risk level) based on high groundwater levels of arsenic in a few states. Cleanup to a more protective standard was judged to be cost-prohibitive in these areas. However, states with less serious arsenic problems are free to set lower, more health-protective standards. New Jersey, for example, has chosen to set the arsenic standard at $5 \mathrm{ppb}$, based on their local cost-benefit calculation (New Jersey DEP, 2004). In addition, states may decide to develop their own MCLs without waiting for the federal mandate, because the federal process is quite slow.

As of 2006, federal primary standards (MCLs, action levels, or maximum residual disinfectant levels) have been established for 80 chemicals in drinking water (see Table 2). Microbiological contaminants (e.g., cryptosporidium, total coliforms, heterotrophic plate counts) are regulated by treatment standards, as are a few other contaminants or conditions (e.g., acrylamide, epichlorhydrin, turbidity). The federal standards for lead and copper are somewhat unique. These 
TABLE 2. Drinking Water Contaminants Regulated by the EPA, with Their Critical Effects and Regulatory Levels

\begin{tabular}{|c|c|c|}
\hline Contaminant & Critical Effects & MCL (ppb) \\
\hline Acrylamide & $\begin{array}{l}\text { Nervous system or blood problems; } \\
\text { increased risk of cancer }\end{array}$ & $\mathrm{TT}^{a}$ \\
\hline Alachlor & $\begin{array}{l}\text { Eye, liver, kidney or blood problems, } \\
\text { anemia; increased risk of cancer }\end{array}$ & 2 \\
\hline Antimony & $\begin{array}{l}\text { Increased blood cholesterol, } \\
\text { decreased blood sugar }\end{array}$ & 6 \\
\hline Arsenic & $\begin{array}{l}\text { Skin damage or circulatory system } \\
\text { problems; increased risk of lung, } \\
\text { bladder, or skin cancer }\end{array}$ & 10 \\
\hline Asbestos & Increased intestinal polyps & $\begin{array}{l}7 \mathrm{MFL}^{b} \\
>10 \mu \mathrm{M}\end{array}$ \\
\hline Atrazine & $\begin{array}{l}\text { Cardiovascular system or } \\
\text { reproductive problems }\end{array}$ & 3 \\
\hline Barium & Increased blood pressure & 2,000 \\
\hline Benzene & $\begin{array}{l}\text { Anemia; decrease in blood platelets; } \\
\text { increased risk of cancer }\end{array}$ & 5 \\
\hline Benzo $[a]$ pyrene & $\begin{array}{l}\text { Reproductive difficulties; increased } \\
\text { risk of cancer }\end{array}$ & 0.2 \\
\hline Beryllium & Intestinal lesions & 4 \\
\hline Bromate & Increased risk of cancer & 10 \\
\hline Cadmium & Kidney damage & 5 \\
\hline Carbofuran & $\begin{array}{l}\text { Blood, nervous system, or } \\
\text { reproductive problems }\end{array}$ & 40 \\
\hline Carbon tetrachloride & $\begin{array}{l}\text { Liver problems; increased risk of } \\
\text { cancer }\end{array}$ & 5 \\
\hline Chloramines (as $\mathrm{Cl}_{2}$ ) & $\begin{array}{l}\text { Eye/nose irritation; stomach } \\
\text { discomfort, anemia }\end{array}$ & $4,000^{c}$ \\
\hline Chlordane & $\begin{array}{l}\text { Liver or nervous system problems; } \\
\text { increased risk of cancer }\end{array}$ & 2 \\
\hline Chlorine $\left(\right.$ as $\mathrm{Cl}_{2}$ ) & $\begin{array}{l}\text { Eye/nose irritation; stomach } \\
\text { discomfort }\end{array}$ & $4,000^{c}$ \\
\hline $\begin{array}{l}\text { Chlorine dioxide } \\
\quad\left(\text { as } \mathrm{ClO}_{2}\right)\end{array}$ & $\begin{array}{l}\text { Anemia; nervous system effects in } \\
\text { infants and young children }\end{array}$ & $800^{c}$ \\
\hline Chlorite & $\begin{array}{l}\text { Anemia; nervous system effects in } \\
\text { infants and young children }\end{array}$ & 1,000 \\
\hline Chlorobenzene & Liver or kidney problems & 100 \\
\hline Chromium (total) & Allergic dermatitis & 100 \\
\hline Copper & $\begin{array}{l}\text { Short-term exposure: gastrointestinal } \\
\text { distress; long-term exposure: liver } \\
\text { or kidney damage }\end{array}$ & $1,300^{d}$ \\
\hline Cyanide (free) & Nerve damage or thyroid problems & 200 \\
\hline Dalapon & Minor kidney changes & 200 \\
\hline Dibromochloropropane & $\begin{array}{l}\text { Reproductive difficulties; increased } \\
\text { risk of cancer }\end{array}$ & 0.2 \\
\hline
\end{tabular}


TABLE 2. (continued)

\begin{tabular}{|c|c|c|}
\hline Contaminant & Critical Effects & MCL (ppb) \\
\hline Dichlorobenzene, 1,2- & $\begin{array}{l}\text { Liver, kidney, or circulatory system } \\
\text { problems }\end{array}$ & 600 \\
\hline Dichlorobenzene, 1,4- & $\begin{array}{l}\text { Anemia; liver, kidney, or spleen } \\
\text { damage; changes in blood }\end{array}$ & 75 \\
\hline Dichloroethane, 1,2- & Increased risk of cancer & 5 \\
\hline Dichloroethylene, 1,1- & Liver problems & 7 \\
\hline $\begin{array}{l}\text { Dichloroethylene, } \\
\text { cis-1,2- }\end{array}$ & Liver problems & 70 \\
\hline $\begin{array}{l}\text { Dichloroethylene, } \\
\text { trans-1,2- }\end{array}$ & Liver problems & 100 \\
\hline Dichloromethane & $\begin{array}{l}\text { Liver problems; increased risk of } \\
\text { cancer }\end{array}$ & 5 \\
\hline $\begin{array}{l}\text { Dichlorophenoxyacetic } \\
\text { acid, 2,4-D }\end{array}$ & $\begin{array}{l}\text { Kidney, liver, or adrenal gland } \\
\text { problems }\end{array}$ & 70 \\
\hline Dichloropropane, 1,2- & Increased risk of cancer & 5 \\
\hline Di(2-ethylhexyl)adipate & $\begin{array}{l}\text { Weight loss, liver problems, or } \\
\text { possible reproductive difficulties }\end{array}$ & 400 \\
\hline Di(2-ethylhexyl)phthalate & $\begin{array}{l}\text { Reproductive difficulties, liver } \\
\text { problems; increased risk of cancer }\end{array}$ & 6 \\
\hline Dinoseb & Reproductive difficulties & 7 \\
\hline Diquat & Cataracts & 20 \\
\hline Endothall & Stomach and intestinal problems & 100 \\
\hline Endrin & Liver problems & 2 \\
\hline Epichlorhydrin & $\begin{array}{l}\text { Increased cancer risk, and over a long } \\
\text { period of time, stomach problems }\end{array}$ & TT \\
\hline Ethylbenzene & Liver or kidney problems & 700 \\
\hline Ethylene dibromide & $\begin{array}{l}\text { Problems with liver, stomach, } \\
\text { reproductive system, or kidneys; } \\
\text { increased risk of cancer }\end{array}$ & 0.05 \\
\hline Fluoride & $\begin{array}{l}\text { Bone fluorosis; mottled teeth in } \\
\text { children }\end{array}$ & 4,000 \\
\hline Glyphosate & $\begin{array}{l}\text { Kidney problems; reproductive } \\
\text { difficulties }\end{array}$ & 700 \\
\hline Gross alpha activity & Increased risk of cancer & $15 \mathrm{pCi} / \mathrm{L}^{e}$ \\
\hline Gross beta activity & Increased risk of cancer & $50 \mathrm{pCi} / \mathrm{L}^{e}$ \\
\hline Haloacetic acids, total & Increased risk of cancer & 60 \\
\hline Heptachlor & $\begin{array}{l}\text { Liver damage; increased risk of } \\
\text { cancer }\end{array}$ & 0.4 \\
\hline Heptachlor epoxide & $\begin{array}{l}\text { Liver damage; increased risk of } \\
\text { cancer }\end{array}$ & 0.2 \\
\hline Hexachlorobenzene & $\begin{array}{l}\text { Liver or kidney problems; } \\
\text { reproductive difficulties; increased } \\
\text { risk of cancer }\end{array}$ & 1 \\
\hline Hexachlorocyclopentadiene & Kidney or stomach problems & 50 \\
\hline
\end{tabular}


TABLE 2. (continued)

\begin{tabular}{|c|c|c|}
\hline Contaminant & Critical Effects & MCL (ppb) \\
\hline Lead & $\begin{array}{l}\text { Infants and children: delays in } \\
\text { physical or mental development; } \\
\text { children could show slight deficits } \\
\text { in attention span and learning } \\
\text { abilities; adults: kidney problems; } \\
\text { high blood pressure }\end{array}$ & $15^{d}$ \\
\hline Lindane & Liver or kidney problems & 0.2 \\
\hline Mercury (inorganic) & Kidney damage & 2 \\
\hline Methoxychlor & Reproductive difficulties & 40 \\
\hline Nitrate & $\begin{array}{l}\text { Infants }<6 \text { months old could become } \\
\text { seriously ill, and, if untreated, may } \\
\text { die; symptoms include shortness of } \\
\text { breath and blue baby syndrome }\end{array}$ & $10,000($ as $\mathrm{N})$ \\
\hline Nitrite & See above & $1,000$ (as $\mathrm{N})$ \\
\hline Nitrate + nitrite & See above & $10,000($ as $\mathrm{N})$ \\
\hline Oxamyl & Slight nervous system effects & 200 \\
\hline Pentachlorophenol & $\begin{array}{l}\text { Liver or kidney problems; increased } \\
\text { risk of cancer }\end{array}$ & 1 \\
\hline Picloram & Liver problems & 500 \\
\hline $\begin{array}{l}\text { Polychlorinated } \\
\text { biphenyls }\end{array}$ & $\begin{array}{l}\text { Skin changes; thymus gland } \\
\text { problems; immune deficiencies; } \\
\text { reproductive or nervous system } \\
\text { difficulties; increased risk of cancer }\end{array}$ & 0.5 \\
\hline Radium-226 and -228 & Increased risk of cancer & $5 \mathrm{pCi} / \mathrm{L}$ \\
\hline Selenium & $\begin{array}{l}\text { Hair or fingernail loss, finger or toe } \\
\text { numbness, circulatory problems }\end{array}$ & 50 \\
\hline Simazine & Problems with blood & 4 \\
\hline Strontium-90 & Increased risk of cancer & $\begin{array}{l}8 \mathrm{pCi} / \mathrm{L} \text { (now } \\
\text { covered } \\
\text { by gross } \\
\text { beta) }\end{array}$ \\
\hline Styrene & $\begin{array}{l}\text { Liver, kidney, or circulatory system } \\
\text { problems }\end{array}$ & 100 \\
\hline 2,3,7,8-TCDD (dioxin) & $\begin{array}{l}\text { Reproductive difficulties; increased } \\
\text { risk of cancer }\end{array}$ & 0.00003 \\
\hline Tetrachloroethylene & $\begin{array}{l}\text { Liver problems, increased risk of } \\
\text { cancer. }\end{array}$ & 5 \\
\hline Thallium & $\begin{array}{l}\text { Hair loss; blood changes; kidney, } \\
\text { intestine, or liver problems }\end{array}$ & 2 \\
\hline Toluene & $\begin{array}{l}\text { Nervous system, kidney, or liver } \\
\text { problems }\end{array}$ & 1,000 \\
\hline Toxaphene & $\begin{array}{l}\text { Kidney, liver, or thyroid problems; } \\
\text { increased risk of cancer }\end{array}$ & 3 \\
\hline TP, 2,4,5- (Silvex) & Liver problems & 50 \\
\hline Trichlorobenzene, 1,2,4- & Changes in adrenal glands & 70 \\
\hline
\end{tabular}


TABLE 2. (continued)

\begin{tabular}{|c|c|c|}
\hline Contaminant & Critical Effects & MCL (ppb) \\
\hline Trichloroethane, 1,1,1- & $\begin{array}{l}\text { Liver, nervous system, or circulatory } \\
\text { problems }\end{array}$ & 200 \\
\hline Trichloroethane, 1,1,2- & $\begin{array}{l}\text { Liver, kidney, or immune system } \\
\text { problems }\end{array}$ & 5 \\
\hline Trichloroethylene & $\begin{array}{l}\text { Liver problems; increased risk of } \\
\text { cancer }\end{array}$ & 5 \\
\hline Trihalomethanes (total) & $\begin{array}{l}\text { Liver, kidney, or CNS problems, } \\
\text { cancer }\end{array}$ & 80 \\
\hline Tritium & Increased risk of cancer & $\begin{array}{l}20,000 \mathrm{pCi} / \mathrm{L} \\
\text { (now coverec } \\
\text { by gross } \\
\text { beta) }\end{array}$ \\
\hline Uranium & $\begin{array}{l}\text { Increased risk of cancer; kidney } \\
\text { toxicity }\end{array}$ & 30 \\
\hline Vinyl chloride & Increased risk of cancer & 2 \\
\hline Xylenes & Nervous system damage & 10,000 \\
\hline
\end{tabular}

Source: U.S. EPA (2006).

${ }^{a} \mathrm{TT}$, treatment technology standard.

${ }^{b}$ MFL, million fibers per liter.

${ }^{c}$ Maximum residual disinfectant level.

${ }^{d}$ Action level.

${ }^{e}$ Picocuries per liter.

standards, known as action levels, are measured at the tap rather than at the source (the drinking water plant). This difference is based on the fact that a home or business plumbing system can be a major source of lead and copper, leaching from pipes, solder, and fixtures.

Secondary standards increase the total list of constituents of concern. These standards, for such chemicals as aluminum, iron, and manganese, are commonly based on taste, odor, or appearance of the water. Some chemicals have both primary and secondary standards (e.g., fluoride), and the secondary standards may be set higher or lower than the MCLs and the federal secondary standards. The secondary standards are also often based on local conditions (U.S. Code of Federal Regulations, 2002). Delivery of municipal water exceeding the secondary standards is allowed, but discouraged.

\section{THE RISK ASSESSMENT PROCESS}

Determination of safe levels for contaminants in drinking water requires a comprehensive system to evaluate the risk of adverse effects from exposure to chemicals and other contaminants. Considering the hundreds of contaminants that can be found using present analytical techniques, the system requires considerable 
resources and expertise. Simple prohibition of chemical contaminants from drinking water is not feasible, because water is a very good solvent, and analytical techniques are exquisitely sensitive. Parts per trillion $\left(1 \times 10^{-12}\right.$, or 1 drop in 1000 backyard swimming pools) can now be quantitated for many chemicals in drinking water. The basic premise of the risk assessment process is that the probability and severity of possible toxic effects of chemicals is related to dose. Therefore, the question is always: How clean must the water be to provide a negligible risk? The science of toxicology has evolved to address this issue.

We can think of toxicology as having started with observations of poisoning of people by plants and animal venoms. As humans developed mines and other industries, occupational poisons such as lead and mercury were documented by their obvious ill effects. About 400 B.C., Hippocrates wrote extensively of poisons and toxicology principles, and 800 years later, the Romans used poisons extensively for political gain. Paracelsus, a doctor and alchemist (1493-1541), is credited with providing the basis for the modern science of toxicology. Although he contributed much to a systematic understanding of toxicologic principles, his observation, summarized as, "the dose makes the poison," is best known.

This approach resulted in a gradual, painstaking accumulation over the next 400 years of observational knowledge about toxic chemicals and their effects on animals and humans. However, it was not until the 1940s that the need for rapid development of antimalarial drugs during World War II led to the development of formal toxicity test procedures using animal models (Gallo, 1996). At first, this involved straightforward testing of single doses of chemicals in animals to determine acute toxic effects and doses. Protocols were then extended for repeated dosing to evaluate the cumulative effects of chemicals. This was strictly for development of drugs, not to characterize toxic effects of chemicals per se. However, the value of the animal tests was self-evident, and they were quickly applied to the development of insecticides. Relative toxicity of chemicals was compared using simple criteria such as the $\mathrm{LD}_{50}$, the dose that will kill $50 \%$ of the test animals within a specified period of time.

In addition to potency, studies in animals are designed to assess toxic mechanisms or concerns, such as acute or longer-term effects, effects on growth and development, effects on reproductive processes, and cancer. The most relevant data are considered to derive from studies in mammals, especially primates, but all data are potentially useful, including mutagenicity tests in microbes (Ames assays). Data from human accidental or occupational exposures to chemicals may also be relevant, as well as the results of epidemiological investigations. The potential exposure to the chemicals through the drinking water supply and other exposure routes must be considered along with the inherent hazards of the chemicals.

Drinking water risk assessment integrates all the available information into estimates of safe levels of chemicals in water. For most efficiency, it is important that the drinking water risk assessment system be integrated with toxicology evaluation programs set up for other purposes. Therefore, studies used to develop guidance on food tolerances for pesticide residues in foods are used 
to help determine acceptable concentrations of the pesticides in drinking water. In addition, inhalation studies intended to develop occupational standards for volatile solvents are incorporated in the risk assessment whenever available. Studies on pharmaceutical products may be relevant, especially for perspectives on mechanisms. Occupational and industrial exposures by multiple routes are also considered. In attempting to determine maximal safe doses, the assessments must consider lifetime exposures at low levels for the entire population as well as potentially susceptible subpopulations such as pregnant women and their fetuses, and the elderly.

A complex risk assessment process was developed in a relatively short time in response to the regulatory mandates. Risk assessment as a specialty barely predates the Safe Drinking Water Act of 1974. The Society for Risk Analysis was chartered in 1980 to serve the growing risk assessment community (Thompson et al., 2005). The regulatory risk assessment process was first discussed at some length in a groundbreaking report of the National Academy of Sciences (NAS) in 1983 (NAS, 1983). This report, entitled, Risk Assessment in the Federal Government: Managing the Process is remembered primarily for its recommendation for separation of risk assessment and risk management, so that risk assessment can be maintained as a scientific process, while risk management brings in the practical and political considerations necessary to resolve a problem. This helped lead to the field of risk assessment as a separate, scientifically driven activity.

Another influential point in the 1983 NAS report was the definition of risk assessment as a four-step process, comprised of hazard identification, doseresponse assessment, exposure assessment, and risk characterization (with an accompanying rationale for this separation into parts). These definitions were also important in providing direction to the growing field of risk assessment.

As the requirements for determination of acceptable maximum exposure levels have grown, so has the list of conventions and assumptions used in risk assessment. One important convention is the separation of risk assessment into cancer and noncancer methods. Cancer risk is estimated quantitatively and the risk of noncancer effects is protected against by using uncertainty or safety factors. This separation derives from the assumption that cancer risks can be estimated using models that are linear through zero dose, whereas noncancer effects are subject to a threshold. Whether or not these assumptions are true, or should be assumed to be true for the protection of public health, is subject to much debate and is discussed at greater length in later chapters.

Current practice for cancer risk assessment involves application of a mathematical model to extrapolate measurable cancer risks at a large dose to a negligible risk level. The negligible risk level is generally considered to be in the range of 1 case in 10,000 to 1 in a million (usually expressed as $10^{-4}$ to $10^{-6}$ risk) over a lifetime of exposure. The standard animal study design for cancer evaluation, using 50 animals per dose group, has a sensitivity level of about $10 \%$ for statistical significance. That is, a $10 \%$ greater incidence of a particular type of tumor in a treated group than in the control group is required to obtain statistical 
significance at the $p<0.05$ level ( 1 chance in 20 that the observation represents random variations rather than a toxic effect caused by the chemical treatment).

It is assumed that one-tenth the dose level cited above will result in a $1 \%$ tumor incidence, one-hundredth of the dose will result in a $0.1 \%$ tumor incidence, and so on. Obviously, whether this assumption is true cannot be determined from the tumor data. A very large study, using hundreds of animals per group, would improve the statistical significance level by only a few-fold. Such a study would cost millions of dollars and still be very far from providing information on toxicity in the dose range of greatest interest (i.e., the relatively low-level environmental exposures). The prediction of tumorigenicity might be extended to a lower dose level by using a biochemical marker that correlates with tumorigenicity, such as mutations or cross-linked DNA. However, this approach is limited by the same type of question; that is, does the amount of DNA change really correlate with the number of tumors at a very low dose level?

Epidemiological studies are potentially much more sensitive, because they can involve many thousands of people. However, these studies are also more prone to uncontrollable bias, multiple interacting risk factors, high background tumor rates, and difficulty in estimating chronic doses. For all these reasons, cancer risk assessment typically requires extrapolation of doses by several orders of magnitude to estimate human population risks on the order of 1 cancer case in 10,000 to 1 million exposed people.

For noncarcinogens, the $10 \%$ incidence threshold for statistical significance still applies if studies use 50 animals. However, among common study types, the number of animals recommended varies widely and may be as low as four per group for some studies in dogs. In addition, the effects may be observed as a significant change in a measurable parameter rather than as a yes/no variable such as the presence or absence of a tumor. A greater than $10 \%$ change in a measured value (e.g., body or organ weight, hormone level, or biochemical marker of a toxic effect) is often the approximate level for a statistically significant change from control values. A $10 \%$ change has also been utilized as an assumed threshold of biological or toxicological significance, although this is not really correct; the degree of perturbation of a system required to produce toxic effects varies according to a host of factors, including the duration of the change induced.

The concept of a threshold for toxic effects recognizes that some changes are too small to be of concern because the organism adapts to the stress. In addition, small amounts of damage can readily be repaired. Doses below this threshold would therefore be tolerable. However, the threshold dose is expected to vary among different people (as well as among different species and strains of animals) because of inherent differences in sensitivity and/or preexisting conditions such as sex, age, pregnancy, or disease. Variations in rate of absorption, distribution, metabolism, and excretion (ADME) of a chemical are expected. The amount of variation can be demonstrated in some physiological systems and estimated in others. Known and unknown variations can be expressed through an uncertainty factor. Traditionally, the variation among humans has been expressed as a factor of 10. That is, if one determines the average dose that is without adverse effects 
in a typical small group of test subjects and divides that number by 10, this dose should be without effect in any person within the entire population. Evaluations of this with real data, such as data on pharmaceutical effect levels (Hattis et al., 1999) or drug half-lives (Ginsberg et al., 2002), show that a factor of 10 is adequate to encompass most of the variability among adults but is not necessarily adequate to protect infants and children.

The same concept is used to account for other sources of variation or uncertainty, such as extrapolation from data in animals to potential effects in humans. The nominal rationale for this is that over a wide range of chemicals tested in humans and in animals, humans are as much as 10 times more sensitive to some of them (and less sensitive to others). Thus, if humans have not been tested, dividing the no-effect animal dose by 10 should be adequate to protect against toxic effects in humans.

Additional factors of 10 are used to extrapolate from observed acute effects to potential chronic effect levels, and from observed toxic effect levels to no observed effect levels. For each additional factor, the toxic effect level observed is divided by another factor of 10 . However, the uncertainties are not necessarily multiplicative, so this strategy is likely to be overprotective. This is not necessarily inappropriate, because it protects people against unknown effects from poorly tested chemicals and provides a powerful inducement for companies that make or use the chemicals to conduct relevant toxicity tests. The possibility of additive effects or other interactions among the numerous chemicals to which people are exposed is an additional reason for caution. The more that is known about a chemical and its interactions, the smaller the uncertainty factor should be.

Risk assessment has always taken a cautionary approach, to ensure that risks have not been underestimated. However, since the very beginning of our formal risk assessment process, risk assessors have been attempting to refine the process to characterize the parameters more accurately: exposure as well as toxic effects. The presumption has been that if we have more data on chemicals and their effects on the human body, the uncertainty in risk assessment will decrease. This may lead to increases in our estimates of acceptable exposures. In practice, little or no trend toward allowing increased exposures has occurred. Other considerations, such as more and better data on susceptible populations, has tended to offset the contribution of improved estimates of exposure and toxic effects. In addition, tremendous improvements in analytical methodology have continued to reveal more chemicals in drinking water, with a resulting demand that they be evaluated and regulated.

The increase in the number of chemicals monitored has resulted in attempts to consider the effects of mixtures. The effects of chemicals may be additive, greater than additive (synergistic), or antagonistic. Interactions among chemicals may occur at every step within an organism (ADME or effects on the sensitive receptor, tissue, or organ). Such interactions are as yet relatively poorly understood and modeled; this is the subject of intense research, as discussed in a later chapter. 
Attempts to better understand and model interactions of chemicals with the body are perhaps the most intense area of research. The development of physiologically based pharmacokinetic models for chemicals has greatly improved our ability to predict the behavior of chemicals in vivo, and thus to replace uncertainty factors with actual data. Credible models of toxicodynamics - the chain of events from interaction of a chemical with a receptor to tissue damage - are still in a relatively primitive stage of development. The basic risk assessment paradigm, as well as the areas of active research, are described in more detail in subsequent chapters.

\section{PUBLIC PERCEPTIONS AND THE PRECAUTIONARY PRINCIPLE}

The risk assessment system must protect public health in the face of uncertainty and recognize the public demand for a clean and safe drinking water supply. Ideally, the assessment of risks should be separated from the process for management of risks, which depends on technical and economic feasibility. Maintaining an independent risk assessment process helps assure the public that true estimates of risk will not be hidden while justifying an economic consideration-although risk-benefit trade-offs are always necessary. The public must be kept informed of the efforts made to ensure the safety of their water as well as of any problems that might occasionally arise.

As we have seen particularly in California in recent years, if people question the safety or quality of their municipal water supply, they will decline to drink it. In the United States, several billion dollars per year are now being spent on bottled water (Squires, 2006) (although the increase in bottled water consumption is by no means limited to the United States; see Doria, 2006). The fact that water quality standards for bottled water are essentially the same as for tap water seems not to be well known (Bullers, 2002; Raj, 2005; Stossel, 2005). However, safety is only one factor; people also choose to drink bottled water for taste, convenience, and even fashion (Doria et al., 2005).

To some extent, choosing bottled water is an example of the public's use of the precautionary principle. They have heard of contaminants in the tap water, and some may even have read the annual consumer confidence report from their municipal water supply company. However, the most important aspect of the use of bottled water is the exercise of choice-the public chooses what they perceive to be a higher-quality product, even if they have no evidence to substantiate this.

This brings up the ultimate rationale and justification for good risk assessments of chemicals in drinking water: our responsibility as risk assessors to ensure the public that their water supply is safe. Unfortunately, much is still unknown about the interactions of most chemicals with the human body, and many new chemicals are being introduced into commerce, and the environment, every year. With tight budgets and an expanding workload, it will be a struggle to keep up to date. The sustained diligence of risk assessment professionals is required to ensure protection of public health while moving the science forward. 


\section{Disclaimer}

The opinions expressed in this chapter are those of the author and not necessarily those of the Office of Environmental Health Hazard Assessment or the California Environmental Protection Agency.

\section{REFERENCES}

Baker MN. 1948. The Quest for Pure Water. American Water Works Association, Denver, CO.

Bullers AC. 2002. Bottled water: better than the tap? FDA Consum 36(4): 14-18. Accessed at: http://www.fda.gov/fdac/features/2002/402_h2o.html.

Doria MF. 2006. Bottled water versus tap water: understanding consumer's preferences. $J$ Water Health 4(2): 271-276.

Doria MF, Pidgeon N, Hunter P. 2005. Perception of tap water risks and quality: a structural equation model approach. Water Sci Technol 52(8): 143-149.

Gallo MA. 1996. History and scope of toxicology. In: Casarett and Doull's Toxicology: The Basic Science of Poisons, 5th ed. Klaassen CD, Amdur MO, Doull J, eds. McGraw-Hill, New York, pp. 3-11.

Ginsberg G, Hattis D, Sonawane B, Russ A, Banati P, Kozlak M, Smolenski S, Goble R. 2002. Evaluation of child/adult pharmacokinetic differences from a database derived from the therapeutic drug literature. Toxicol Sci 66(2): 185-200.

Hattis D, Banati P, Goble R. 1999. Distributions of individual susceptibility among humans for toxic effects: How much protection does the traditional tenfold factor provide for what fraction of which kinds of chemicals and effects? Ann N Y Acad Sci 895: 286-316.

Hueper WC. 1960. Cancer hazards from natural and artificial water pollutants. Proceedings of the Conference on the Physiological Aspects of Water Quality. U.S. Public Health Service, Washington, DC.

Lederberg J. 1969. We're so accustomed to using chlorine that we tend to overlook its toxicity. Washington Post, May 3, p. A15.

NAS (National Academy of Sciences). 1983. Risk Assessment in the Federal Government: Managing the Process. National Research Council, National Academies Press, Washington, DC.

New Jersey DEP (Department of Environmental Protection). 2004. Safe Drinking Water Act Rules: Arsenic. Adopted November, 4. NJDEP, Trenton, NJ Accessed at: http:// www.nj.gov/dep/rules/adoptions/arsenic_rule7-10.pdf.

Okun DA. 2003. Drinking water and public health protection. In: Drinking Water Regulation and Health. Pontius FW, ed. Wiley, Hoboken, NJ, pp. 3-24.

Page T, Talbot E, Harris RH. 1974. The Implications of Cancer-Causing Substances in Mississippi River Water. Environmental Defense Fund, Washington, DC.

Page T, Harris RH, Epstein SS. 1976. Drinking water and cancer mortality in Louisiana. Science 193: 55.

Pontius FW, ed. 2003. Drinking Water Regulation and Health. Wiley, Hoboken, NJ.

Raj SD. 2005. Bottled water: How safe is it? Water Environ Res 77(7): 3013-3018. 
Squires S. 2006. Testing the waters. Washington Post July 4, p. HE01. Accessed at: http://www.washingtonpost.com.

Stossel J. 2005. Is bottled water better than tap? Commentary. ABC News, May 6. Accessed at: http://abcnews.go.com.

Thompson KM, Deisler PF, Schwing RC. 2005. Interdisciplinary vision: the first 25 years of the Society for Risk Analysis (SRA), 1980-2005. Risk Anal 25(6): 1333-1386.

U.S. Code of Federal Regulations. 2002. CFR part 143, National Secondary Maximum Contaminant Levels. 44 FR 42198. Accessed at: www.access.gpo.gov/nara/cfr/waisidx _02/40cfr143_02.html.

U.S. DHEW (Department of Health, Education, and Welfare). 1969. Public Health Service Drinking Water Standards, 1962. Public Health Service Publication 956. Reprinted September 1969. U.S. DHEW, Washington, DC. (As cited in U.S. EPA, 1999.)

U.S. EPA (Environmental Protection Agency). 1972. Industrial Pollution of the Lower Mississippi River in Louisiana. U.S. EPA, Region VI, Dallas, TX.

1999. 25 Years of the Safe Drinking Water Act: History and Trends. U.S. EPA, Washington, DC. Accessed at: http://permanent.access.gpo.gov/websites/epagov/www. epa.gov/safewater/sdwa/trends.htm.

2001. Controlling disinfection by-products and microbial contaminants in drinking water. Chapter 2 in: A review of Federal Drinking Water Regulations in the US (by James Owens). EPA/600/R-01/110. U.S. EPA, Washington, DC. Accessed at: http://www.epa.gov/NRMRL/pubs/600r01110/600r01110.htm.

2004. Safe Drinking Water Act 30th Anniversary: Understanding the Safe Drinking Water Act. EPA/816/F-04/030. U.S. EPA, Washington, DC. Accessed at: http://www. epa.gov/safewater/sdwa/30th/factsheets/understand.html.

. 2006. List of Drinking Water Contaminants and MCLs. Office of Water, U.S. EPA, Washington, DC. Accessed at: http://www.epa.gov/safewater/mcl.html. 
